\title{
Wage Level as One of the Most Important Indicators of the Quantitative Aspect of the Standard of Living of the Population and Selected Indicators of Economic Maturity in OECD Member Countries
}

\author{
Diana Bilkova \\ University of Economics, Prague; Faculty of Informatics and Statistics; Department of Statistics and Probability \\ Sq. W. Churchill 1938/4, 13067 Prague3, Czech Republic \\ E-mail.bilkova@vse.cz; Diana.bilkova@vse.cz \\ cross'ref $^{\text {http://dx.doi.org/10.5755/j01.ee.31.3.23441 }}$
}

The present paper focuses on the comparison of wage levels across OECD countries, the research data coming from an official OECD website. The following eight variables are employed in this study - the average wage, minimum wage, GDP per capita, tertiary education attainment, employment ratio, trade unions, labour productivity and inflation rate. The average wage represents the main explained variable in regression and correlation analysis, the remaining seven variables being used as potential explanatory ones. In order to compare living standards in different countries, average and minimum wages as well as per capita GDP data were adjusted to relative purchasing power parity. The principal objective was to identify which explanatory variables statistically significantly affect the average wage. The analysis showed that only three of them - namely the employment ratio, GDP per capita and labour productivity - have a significant effect at a 5\% statistical level. The regression hyperplane with a forward stepwise selection was applied. Nine clusters of OECD countries were created based on both all the eight variables and four of them selected in regression analysis (the average wage and three explanatory ones) with the aim to identify the countries that coexist in the same cluster. Ward's method and Euclidean distance are utilized in cluster analysis, the number of clusters being determined with the use of the Dunn index. The study also aims at the prediction of the average wage by 2022, which was made via exponential smoothing of time series. (The greatest purchasing power is reported by Luxembourg, Switzerland, Iceland, the U.S., the Netherlands, Denmark, Norway and Austria, the highest average wage growth rate by 2022 being expected in the Baltic and some other post-communist countries.)

Keywords: Average Wage; GDP per Capita; Employment Ratio; Labour Productivity; Purchasing Power Parity; Regression Analysis, Cluster Analysis, Ward's Method; Euclidean Distance; Dunn's index; Time-Series Analysis; Exponential Smoothing.

\section{Introduction}

An extensive body of literature exists on the issue of different employee wages, household income and other relevant indicators of the standard of living and the labour market that are indicative of both regional and countryspecific inequalities. Alderson \& Nielsen (2002), for example, conducted one of the first systematic, crossnational investigations into income inequality, showing that globalization better explains the emerging longitudinal trend of increasing inequality in many industrial countries than cross-sectional inequality differences between them. Employing data for hourly wages in 19 OECD countries over the period 1973-1999, Holden \& Wulfsberg (2008) reject the hypothesis of the absence of the downward rigidity of industry nominal wages. Clark (2005a) suggests that despite rising wages and falling hours worked, overall job satisfaction is either unchanged or in decline, ample evidence pointing to increased inequality. Baccaro \& Rei (2007) engage in an econometric analysis comparing several estimators and specifications, providing evidence for neither direct nor indirect labour market institutions' effects on the unemployment rate. Using the 1973-1998 data from eleven OECD countries, Koeniger, Leonardi \& Nunziata (2007) indicate that changes in those institutions (e.g. unemployment insurance, trade unions, employment protection regulations and minimum wage) can account for much of the change in wage inequality among male workers. Nunziata (2005) performs an empirical analysis of labour cost determinants in OECD countries with particular reference to the impact of the above institutions, showing that labour market regulations over the period 1960-1994 can explain a large part of the labour cost rise when the productivity is monitored. Based on a new global database of bilateral migrant population by educational attainment, Docquier, Ozden \& Peri (2013) quantify the labour market effects of migration flows in OECD countries during the 1990s, concluding that immigration had a positive effect on wages of less educated natives, average wages staying the same or slightly increasing. Rueda \& Pontusson (2000) compare the distribution of employment income via pooled crosssectional time-series analysis of wage inequality determinants in 16 OECD countries from 1973 to 1995 , finding out that the differences between social and liberal market economies shape the way political and institutional variables influence wage inequality. Extending the taxonomy of those variables, a chapter in the 2005b monograph by Clark underlines that pay for work done is a critical element of job satisfaction, using the 1997 ISSP 
data that cover 14,000 workers across 19 OECD countries. Kus (2012) detects a strong correlation between some financialization indicators and income inequality in advanced countries using comparative data from 20 OECD countries between 1995 and 2007. Covering the situation from 1945 to 2001 in the present nine OECD countries, the study by Atkinson (2003) highlights the disagreements over both data on and explanation of income inequality. Fortin (2005) applies data from the World Value Surveys $(1990,1995,1999)$ to explore the effect of gender role attitudes and work values on women's labour-market results across 25 OECD states, anti-egalitarian views displaying a strong negative association with female employment rates and the gender pay gap. A pooled, crosssectional time series analysis done on data from 19 OECD countries over the period 1970-1996 by Macinko, Shi $\&$ Starfield (2004) reveals that the Theil measure of wage inequality is positively and statistically significantly linked to infant mortality rates. Atkinson (2007) notes that the earnings inequality in the OECD countries grew considerably from 1980, which can be explained by a steady increase in demand for skilled labour due to skill-biased technical change and the growing exposure of unskilled workers to global competition. Germany's compressed wage structure being considered as the main cause of the difference between German and US (un)employment rates, Freeman \& Schettkat (2001) maintain that part of the wage compression is due to a narrower skills distribution in Germany. Using comparable micro-data from the Luxembourg Income Study, Bardasi \& Gornick (2008) examine wage gaps between part- and full-time female workers in six OECD countries in the mid-1990s, assessing cross-national variation in the direction, magnitude and composition of a differential between part-time and full-time wages. Falk \& Wolfmayr (2008) offer further insights into the employment effects of international service outsourcing based on a sample of five EU countries' industries, nonmanufacturing sector's results revealing that services purchased from low-wage countries exert a statistically significant but rather small negative impact on employment. Applying a statistical technique that disentangles a potential bi-directional feedback between wages and productivity, Millea (2002) investigates wage strategies in six industrialized countries with various labour market institutions, indicating that conventional and efficiency wage practices vary across the industrialized countries. Gannon, Plasman, Ryex \& Tojerow (2007) show the interaction between significant inter-industry wage differentials and the gender wage gap in six countries utilizing the 1995 European Structure of Earnings Survey employer-employee data set. The wage inequality gap having widened much more in the U.S. than in Europe since the 1970s, Guvenen, Kuruscu \& Ozkan (2013) conclude that the inequality arises from differences between individuals in their ability to acquire new skills as well as from the so-called idiosyncratic shocks. Applying the Keynesian model of demand and productivity growth to eight OECD countries in 1960-2000, Naastepad \& Storm (2006) report that demand in France, Germany, Italy, the Netherlands, Spain and the U.K. is wage-led, contrary to profit-let demand regime in Japan and the U.S.
Van Reenen (2011) describes recent trends in the wage and skill distribution, stressing that technology-related increase in demand for skilled workers contributed to the wage inequality which has spread worldwide from the U.S. and the U.K. since the late 1970s. Utilizing low-income countries data, Van Rijckeghem \& Weder (2001) confirm through multivariable regression analysis based on crosscountry averages that there is a statistically and economically significant relationship between relative civil service pay and local government corruption. Dustmann \& Glitz (2010) analyse differences in the cyclical employment/wage pattern between immigrants and natives in Germany and the U.K., significantly larger unemployment responses to economic fluctuations being recorded among immigrants within both low- and highskill groups. Revising standard explanations of wage inequality differential trends - i.e. that the supply of skills grew faster in Europe than in the United States, or that the European labour market institutions prevented an increase in inequality -, Acemoglu (2003) argues that those institutions create wage compression and encourage investment in technologies, the productivity of low-skilled workers being increased, which implies less skill-biased inequality trends in Europe than in the U.S. Sjoberg (2008) assesses empirically the function of corporate governance in explaining earnings inequality differences between OECD countries over the period 1979-2000, highlighting, e.g. the role of the stock market in channelling capital to corporations, the extent of acquisitions and mergers, or the protection of minority shareholders. Employing micro data from 15 countries, Leuven \& Oosterbeek (2004) verify the hypothesis that wage differentials between skill groups are in line with a supply and demand framework, about a third of the variation in relative wages being explained by the differences in net supply of skill groups. Lucifora, McKnight \& Salverda (2005) review the patterns of low pay in the long run and life-cycle earnings in European countries, showing that minimum wages and trade unions play an important role in reducing wage inequalities. Johnston \& Hancke (2009) examine different levels of wage restraint in EMU member states since the euro introduction. Suggesting that a substantial share of revenues from increased corporate taxes is lost due to a decline in income, Bartelsman \& Beetsma (2003) present evidence of income shifting in response to differences in corporate tax rates for selected OECD countries. Şener (2001) constructs a general equilibrium model of R \& Ddriven growth and knowledge-based trade of high-quality products between two countries, indicating that a product replacement mechanism along with a job-matching process generates the so-called Schumpeterian unemployment. Wolff \& Reinthaler (2008) measure the effectiveness of public subsidies for business $\mathrm{R} \& \mathrm{D}$ in a panel of OECD countries, expenditure for business research rising more than employment, which signals a potential increase in scientists' wages. Soskice \& Iversen (2000) prove the importance of monetary rules for the equilibrium rate of employment when there are not many price- and wagesetters. Looking at the differences and persistence of regional unemployment rates in six transition countries, Bornhorst \& Commander (2006) show that while the outflow of labour seems to be consequential in many 
regions with high unemployment, there are also signs of wage flexibility. Pollin, Burns \& Heintz (2004) provide empirical evidence on issues raised by the global antisweatshop movement, finding no consistent relationship between wage and employment growth, increases in retail prices necessary to absorb the costs of raising wages being within the affordable price range. Applying new microdata from many surveys of random samples of over 200,000 individuals conducted between 1990 and 1997, Blanchflower (2001) explores labour markets of 23 transition countries suggesting that the micro-econometric structure of unemployment regression equations for Eastern and Western Europe is similar. Employing a panel of OECD countries in the period 1960-2000, Checchi \& Garcia-Peñalosa (2010) argue that personal income inequality is affected by the wage differential, labour share and unemployment rate, the overall effect of these institutions being ambiguous. Using data on 55,082 companies operating in nine European countries between 1996 and 2003, Arulampalam, Devereux \& Maffini (2012) calculate the long-term elasticity of labour costs with respect to income tax rate, finding out that an exogenous tax rise by $\$ 1$ would reduce the wage by 49 cents. Plasman, Rusinek \& Rycx (2007) use a harmonized matched employer-employee database to examine the impact of multi-level collective bargaining on wages in the manufacturing sector in Denmark, Belgium and Spain, indicating that, overall, single-employer bargaining has a positive effect on wage levels and dispersion. A preliminary draft by Gaston \& Nelson (1997) attends to two issues that received limited attention in previous studies - namely "the implications of recent research on political economy for discussion of the openness-wages or openness-employment link; and the implications of imperfectly competitive markets". Having reviewed the theoretical framework for evaluating the relationship between international trade and wages, the HeckscherOhlin-Samuelson model and current research outcomes, the authors used their critical findings as the basis for further empirical research.

There are eight post-communist countries (the Czech Republic, Hungary, Poland, the Slovak Republic, Slovenia and the three Baltic countries) among the current 36 OECD member states. The four Central European ones (the Czech Republic, Hungary, Poland and Slovakia) form the socalled Visegrad Group, often called V4. Cooperation between the V4 states is important not only in purely political, but in economic terms as well. Having much in common, these fast-growing economies keep on strengthening their market positions. The three Baltic postSoviet countries (Lithuania, Latvia and Estonia) share both the geographical location and a common historical fate within the former USSR. South European countries have been facing an influx of migrants; Greece, Spain and Portugal having also confronted significant economic problems until recently. Geographically close Scandinavian countries are all economically mature, which is also the case in the developed continental ones. The two Anglo-Saxon countries are bound by their intertwined histories and culture. Non-European countries are divided according to their economic maturity.
The raison d'être of the OECD and the purpose of its policy is to stimulate long-term economic development and cooperation not only between member states but also with non-member ones. The OECD brings together democratic developed countries which produce more than two-thirds of the world's goods and services, maintaining economic relations and promoting international trade. Recently, the OECD has played an active role in addressing the challenges of economic globalization. For the smooth functioning of the OECD and other transnational groupings of states, it is essential to know how member countries differ from and resemble each other in terms of their historical and long-term economic development and geographical location so that the groups of the most similar countries can be identified. This is also the main objective of the present study, the composition of the groups being based on the eight selected economic indicators. The average annual gross wage was chosen as the primary variable, representing an important factor of the standard of living. The paper sets out to detect and measure possible statistically significant effects of the remaining seven variables on the average annual gross wage. Modelling the long-run trend of the primary variable, allowing to develop forecasts of average wages up to 2022, is another research goal.

\section{Database}

Data and variable names come from the official OECD website, the present analysis covering all the member countries. The eight variables are used, indicated in shortened forms in the text. The average annual gross wage - average wage - in 2017 constant prices in USD after conversion to purchasing power parity (PPP) is the main research variable, the study focusing on its development over the period 2000-2017. The other seven variables based on the 2017 data are as follows: real annual minimum wage in USD after the PPP adjustment - minimum wage; gross domestic product per capita in USD PPP (expenditure approach) - GDP per capita; share of the population (in \%) between 25 and 64 years of age with completed tertiary education - tertiary education; annual employment ratio (in $\%$ ) of the population between 15 and 64 years employment ratio; annual trade union density (in \%) - trade unions; labour productivity measured by GDP per hour worked in USD PPP - labour productivity, and consumer price indices (CPI) representing change in 2017 from the previous year (in \%) - inflation. (Minimum wage legislation not being enacted in some countries - namely Austria, Denmark, Finland, Italy, Norway, Sweden and Switzerland - , the minimum wage is then considered as zero.) The above economic indicators were chosen from a number of other variables available as they are assumed to optimally characterize and compare the economic levels of the OECD member countries.

The data include employees in both business and nonbusiness sectors of the economy. The wage is paid to an employee for work done in the private corporate (business) sphere, while the salary is earned in the state budgetary (non-business) sector. Within the present study, both wages and salaries are under the umbrella term of "wage". Data were processed using SAS and Statgraphics software packages and Microsoft Excel spreadsheet. Table 1 shows 
Diana Bilkova. Wage Level as One of the Most Important Indicators of the Quantitative Aspect of the Standard of...

the division of all 36 OECD member countries into nine blocks according to their geographical location, historical background and long-term economic development. (Country codes are taken from the website of the Ministry of the Interior of the Czech Republic.)

There are the following nine groups of OECD member states: Continental block of advanced Western European countries; Scandinavian block; Anglo-Saxon block containing Ireland and the United Kingdom; SouthEuropean block; Baltic block of three OECD countries that were formerly part of the Soviet Union; Central-European block encompassing former socialist countries; NorthAtlantic block including only Iceland; Advanced nonEuropean block and Developing non-European block of the so-called newly industrialized countries.

Blocks of Similar OECD Countries (Incl. International Codes)

Table 1

\begin{tabular}{|c|c|c|c|c|c|c|c|}
\hline \multicolumn{8}{|c|}{ Block } \\
\hline Continental & \multicolumn{2}{|r|}{ Scandinavian } & \multicolumn{2}{|r|}{ Anglo-Saxon } & \multicolumn{2}{|c|}{ South-European } & Baltic \\
\hline $\begin{array}{ll}\text { 1. } & \text { Austria (AUT) } \\
\text { 2. } & \text { Belgium (BEL) } \\
\text { 3. } & \text { France (FRA) } \\
\text { 4. } & \text { Germany (DEU) } \\
\text { 5. } & \text { Luxembourg (LUX) } \\
\text { 6. } & \text { Netherlands (NLD) } \\
\text { 7. } & \text { Switzerland (CHE) }\end{array}$ & \multicolumn{2}{|r|}{$\begin{array}{l}\text { Denmark (DNK) } \\
\text { Finland (FIN) } \\
\text { Norway (NOR) } \\
\text { Sweden (SWE) }\end{array}$} & \multicolumn{2}{|r|}{$\begin{array}{l}\text { Ireland (IRL) } \\
\text { United Kingdom (GBR) }\end{array}$} & \multicolumn{2}{|c|}{$\begin{array}{ll}\text { 1. } & \text { Greece (GRC) } \\
\text { 2. } & \text { Italy (ITA) } \\
\text { 3. } & \text { Portugal (PRT) } \\
\text { 4. } & \text { Spain (ESP) }\end{array}$} & $\begin{array}{ll}\text { 1. } & \text { Estonia (EST) } \\
\text { 2. } & \text { Latvia (LVA) } \\
\text { 3. } & \text { Lithuania (LTU) }\end{array}$ \\
\hline \multicolumn{8}{|c|}{ Block } \\
\hline Central-European & & North & atic & \begin{tabular}{|l} 
Advanced non \\
\end{tabular} & European & & oping non-European \\
\hline $\begin{array}{ll}\text { 1. } & \text { Czech Republic (CZE) } \\
\text { 2. } & \text { Hungary (HUN) } \\
\text { 3. } & \text { Poland (POL) } \\
\text { 4. } & \text { Slovak Republic (SVK) } \\
\text { 5. } & \text { Slovenia (SVN) }\end{array}$ & & Iceland & & $\begin{array}{ll}\text { 1. } & \text { Australia (AU } \\
\text { 2. } & \text { Canada (CAN } \\
\text { 3. } & \text { Israel (ISR) } \\
\text { 4. } & \text { Japan (JPN) } \\
\text { 5. } & \text { New Zealand } \\
\text { 6. } & \text { South Korea ( } \\
\text { 7. } & \text { United States } \\
\end{array}$ & $\begin{array}{l}\text { NZL) } \\
\text { OR) } \\
\text { JSA) }\end{array}$ & $\begin{array}{l}1 . \\
2 . \\
3 .\end{array}$ & $\begin{array}{l}\text { e (CHL) } \\
\text { sico (MEX) } \\
\text { xey (TUR) }\end{array}$ \\
\hline
\end{tabular}

Source: Own research; https://www.mvcr.cz

\section{Theory and Methods}

\section{Regression and Correlation Analysis}

The regression and correlation analysis of the 2017 data was performed; for details of this approach, see, e.g. Darlington \& Hayes (2017). The average wage represents an explained (dependent) variable, the remaining seven variables being used as potentially explanatory (independent) variables. The normality of the distribution of the variables was verified both visually and by conducting the Kolmogorov-Smirnov goodness-of-fit test, the chi-square test not being run because of too small a number of observations.

The regression hyperplane with seven potentially explanatory variables having been considered, stepwise regression with the forward selection method was used to determine the set of explanatory variables that have a statistically significant effect on the explained variable. The backward selection approach led to the same result. Three explanatory variables were inserted into the model, namely the employment ratio, GDP per capita and labour productivity. All individual t-tests and total F-test are significant at the $5 \%$ level. The multiple determination coefficient shows that about $80.43 \%$ of the variability of the observed average wage values was explained by the selected regression hyperplane and the three explanatory variables. A Durbin-Watson statistic of 2.47733 lies in the interval $(1.4 ; 2.6)$. Being close to 2 , this value indicates that there is no problem with autocorrelation. The matrix of double correlation coefficients for verification of the existence of serious multicollinearity between the explanatory variables suggests that the absolute value of any of the correlation coefficients does not exceed 0.5 . This means that there is no problem with multicollinearity. The residual plots correspond to the model with the three selected explanatory variables, the residues being considered as random. In addition to the visual assessment, the Glejser test was undertaken, not showing any problems with heteroscedasticity.

\section{Cluster Analysis}

The basics of this multidimensional statistical method are explained, for example, by Rencher \& Christensen (2012). Ward's method and the Euclidean distance are the most widely used techniques that are also employed in this cluster analysis of the 2017 data, performed separately for both all the eight variables and only four of them, namely the average wage and the three explanatory variables selected in the regression and correlation analysis.

In the Ward's method, which is one of the hierarchical clustering approaches, the procedure is not based on the optimization of distances between clusters. The minimization of heterogeneity of clusters is carried out according to an increase in the intra-cluster sum of squares of objects' deviations from the centre (centroids) of the clusters. Ward's method tends to remove too small clusters, thus inclining to form those of roughly the same size, which is a welcome feature for the clustering of the OECD countries. As for the measurements of the distance and similarity of objects, the need to reinforce the influence of variables is taken into account. Since there is no such need in this case - points with the same distance from the centre lying on a circle -, the Euclidean distance was chosen.

In cluster analysis, there are different methods and recommendations for determining the optimal number of clusters. However, they do not justify any definitive conclusions because cluster analysis is basically a reconnaissance approach, not a statistical test. Exposition and clarification of the resulting hierarchical structure depend on the context. Theoretically, there are several 
possible approaches to determining the best number of clusters possible. One of the validation indices is the well-established Dunn index. It represents the ratio of the smallest inter-cluster distance to the largest one, the index values ranging from zero to infinity, high ones indicating the optimal number of clusters. In the present study, the Dunn index was also applied, nine clusters being determined as optimal.

\section{Time Series Analysis}

The essence of time series analysis is described in detail in, e.g. Brockwell \& Davis (2002). In the context of the trend development, exponential smoothing was done within the analysis of average wage time series to predict the average wage over the next five years. Exponential smoothing is one of the adaptive approaches to modelling time series, using the weighted least squares method, with scales exponentially decreasing towards the past. Its advantage lies in the fact that the latest observations have the highest weights. Appropriate exponential smoothing was selected applying interpolation criteria. Figures 1 and 2 present the results of Brown's and Holt's linear exponential smoothing, respectively, as the most suitable approaches to the time series of the United States and Lithuania, which were selected as examples. Similar calculations have been done for the remaining 34 OECD member countries. In the case of Holt's exponential smoothing, the statistical software automatically evaluates the most advantageous combinations of equalization constants $\alpha$ and $\beta$. Based on an analysis of average wage time series, predictions of average wage developments for the next five years were constructed.

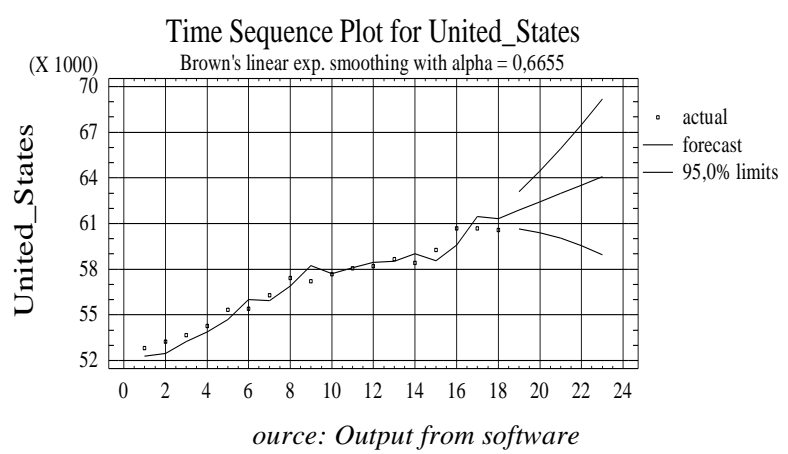

Figure 1. Brown's Linear Exponential Smoothing $(\alpha=0.6655)$ for Time Series of Average Wage in the United States

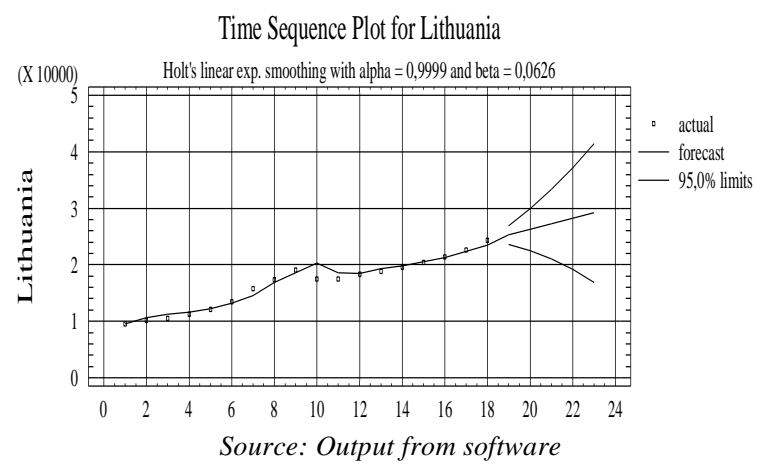

Figure 2. Holt's Linear Exponential Smoothing $(\alpha=0.9999$ and $\beta=0.0626$ ) for Time Series of Average wage in Lithuania
Figures 3 and 4 plot corresponding sample residual autocorrelation functions, Figures 5 and 6 illustrating sample residual partial autocorrelation functions. Brown's and Holt's linear exponential smoothing is satisfactory, a non-systematic component not exhibiting autocorrelation. Durbin-Watson statistics are close to 2, i.e. within the interval $(1.4,2.6)$. Random failures can be therefore considered as independent.

The quality of models created for the average wage in each country was verified, based on which the prediction for the next five years was made. Annual time series for the period 2000-2017 were shortened by $m=5$ observations, i.e. for the 2013-2017 period, predictions for these five years being constructed using the appropriate exponential smoothing.

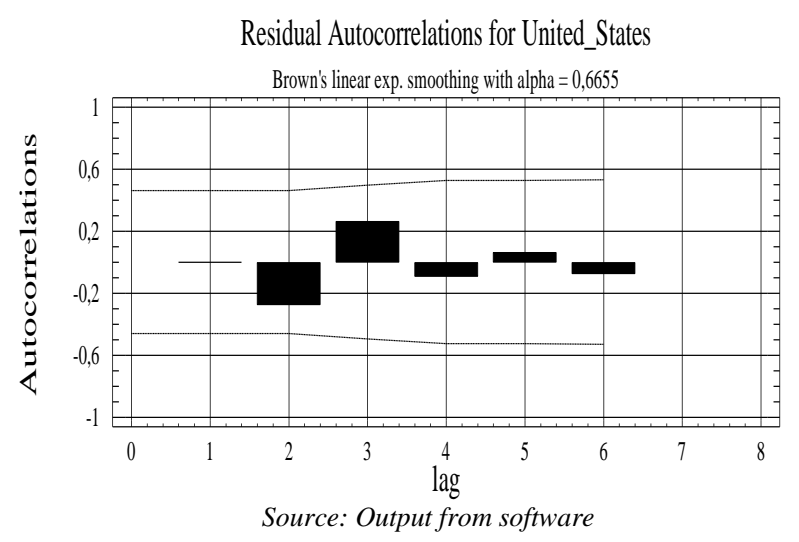

Figure 3. Sample Residual Autocorrelation Function for Time Series of Average Wage in the United States

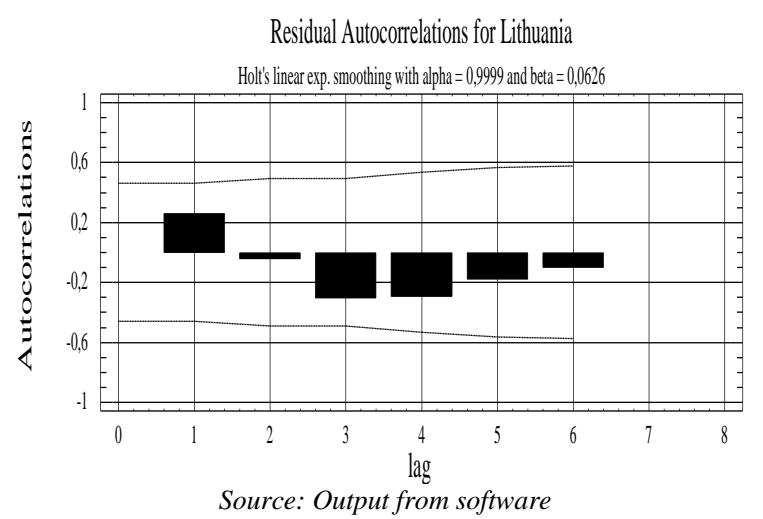

Figure 4. Sample Residual Autocorrelation Function for Time Series of Average Wage in Lithuania

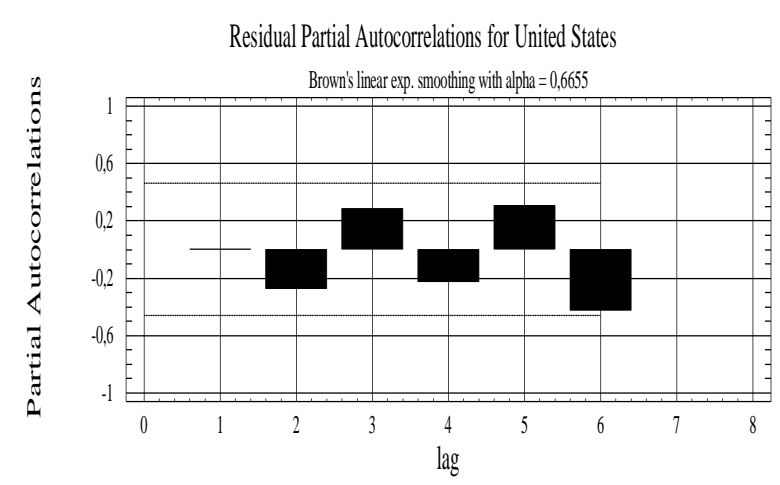

ource: Output from software

Figure 5. Sample residual partial autocorrelation function for time series of average wage in the United States 
Diana Bilkova. Wage Level as One of the Most Important Indicators of the Quantitative Aspect of the Standard of...

Deviations between the predicted and actual values were calculated as

$$
\Delta_{t}(i)=P_{t}(i)-y_{t+i}
$$

where $P_{t}(i)$ is the forecast of the monitored indicator at time $t$ of $i$ time units forward (prediction horizon) and $y_{t+i}$ is the real value of the predicted indicator at time $t+i$. These deviations are called predictive errors for a given time $t$ and the prediction horizon $i$. If $\Delta_{t}(i)<0$, this is the so-called undervalued prediction, and if, on the other hand, $\Delta \mathrm{t}(i)>0$, an overvalued prediction occurs.

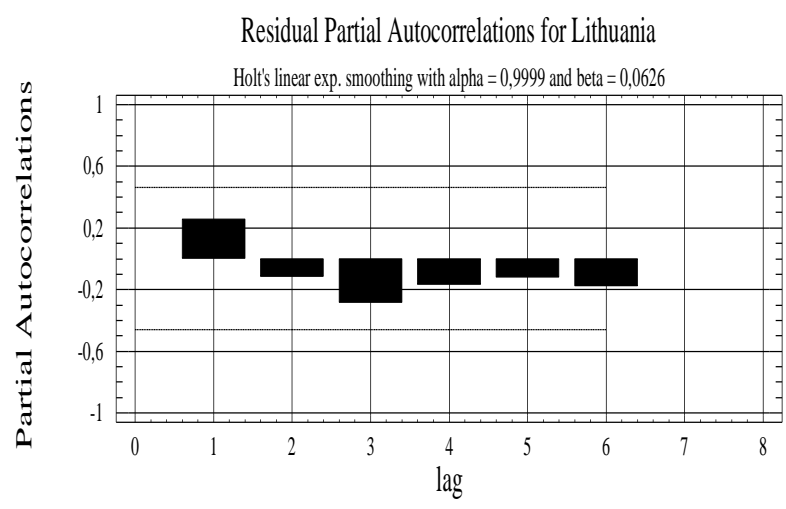

Source: Output from software

Figure 6. Sample Residual Partial Autocorrelation Function for Time Series of Average Wage in Lithuania

The Theil mismatch coefficient (Theil index II) is a frequently used measure of the variability of relative predictive errors

$$
T_{H}^{2}=\frac{\sum_{t=1}^{m}\left[P_{t}(i)-y_{t+i}\right]^{2}}{\sum_{t=1}^{m} y_{t+i}^{2}} .
$$

This mismatch index can be only non-negative. It gets the lower zero boundary only in the case of a flawless prognosis, where $P_{t}(i)=y_{t+i}$. The more the Theil coefficient deviates from zero, the more the prediction differs from an ideal prognosis. The root of the index can be interpreted as a relative predictive error. See Bilkova (2019), too.

For example, the results show that when constructing extrapolation predictions of the average wage, average errors of $1.543 \%$ and $6.571 \%$ (for the U.S. and Lithuania, respectively) occurred. The values of the Theil coefficient and the relative predictive error indicate the high quality of exponential smoothing models. A similar verification of the suitability of the chosen smoothing models was also carried out for the other analysed countries.

\section{Results and Discussion}

The world economy has been heading toward a five per cent rate of unemployment, the lowest over the last four decades. A more relaxed budgetary policy has supported the economic growth (its effects are apparent in about three quarters of the OECD countries), tax reliefs (e.g. recent US cuts) also playing their role.
However, a significant expansion in the global economy has peaked, the growth prognosis for many countries getting worse. Most countries are expected to stagnate or even decline. Given the trade war and other risks are looming in an unprecedentedly interdependent world, escalation of restrictive measures, which hamper further economic growth, should be avoided.

With regard to advanced OECD countries, the comparison of their living standards includes some problematic aspects. Specifically, comparing average wage levels in Western and Eastern European countries is not conclusive and accurate enough, the former countries reporting both higher nominal wages and higher prices of consumer goods and services. It is therefore logical to compare wages when they are converted into purchasing power parities. Then, the differences in national average wages between Western and Eastern Europe are relatively lower. The same is true for other indicators such as the minimum wage, GDP per capita and labour productivity.

Based on data 2017, most OECD member countries witness low inflation rates ranging from $0.24 \%$ (Israel) to $2.93 \%$ (Latvia), the $3 \%$ threshold being crossed only by Estonia (3.4\%), Lithuania (3.7 \%), Mexico (6.04\%) and, in the extreme, Turkey $(11.14 \%)$. With the exception of the latter two countries, the Baltic states, which used to be a part of the Soviet Union, experience higher rates of inflation than in the vast majority of OECD countries.

Based on the 2017 data again, extremely high average wages exceeding USD 60,000 are paid in Luxembourg $(\$ 63,062)$, Switzerland $(\$ 62,283)$, Iceland $(\$ 61,787)$ and the United States $(\$ 60,558)$. High average wages between USD 50,000 and 60,000 are reported in the Netherlands $(\$ 52,877)$, Denmark $(\$ 51,466)$, Norway $(\$ 51,212)$ and Austria $(\$ 50,349)$, wages in Belgium and Australia being slightly lower ( $\$ 49,675$ and $\$ 49,126$, respectively). Canada and Germany have relatively high average wages $(\$ 47,622$ and $\$ 47,585$, respectively), Ireland $(\$ 47,653)$, which suffered major economic problems at the beginning of the global financial crisis, also belonging to this group. The only post-communist OECD country which reports average wages higher than USD 30,000 is Slovenia $(\$ 34,933)$. In eleven other states, employees earn an average wage not exceeding this amount. They are mainly former socialist countries of Central and North-Eastern Europe such as Hungary $(\$ 22,576)$, Latvia $(\$ 23,683)$, Lithuania (\$24,287), Slovakia $(\$ 24,328)$, Estonia $(\$ 24,336)$, the Czech Republic $(\$ 25,372)$ and Poland $(\$ 27,046)$. This cluster also includes Portugal $(\$ 25,367)$ and Greece $(\$ 26,064)$, the latter country having recovered from the most dramatic recession effects. There are also two non-European less developed countries in this group, namely Chile $(\$ 25,879)$ and Turkey $(\$ 26,056)$. The lowest average wage in all of the OECD countries is paid in Mexico (\$15,314).

This is clear from average wage growth rates of the OECD countries (except for Turkey, whose data were not available) that before the economic downturn, very high growth rates were reported by all Baltic countries. The average wage was increasing by $9.37 \%$ a year on average in Estonia (between 2003 and 2007), $9.49 \%$ in Latvia (2004-2007) and $11.19 \%$ in Lithuania (2004-2008). Extreme negative average wage growth rates were 
recorded in Iceland. Having dropped by an average of $12.88 \%$ per annum at the very onset of the crisis in 2008 and 2009 , they climbed by $10.15 \%$ in 2017 . An obvious annual decline was experienced in the Baltic countries in 2009, particularly in Latvia and Lithuania where average wages fell by $9.71 \%$ and $8.21 \%$, respectively.

Only three explanatory variables were inserted into the model as statistically significant at a $5 \%$ level in a positive direction, namely the employment ratio, GDP per capita and labour productivity. The sample regression hyperplane has the following form

Average wage $=-20,402.5+420.915 *$ employment ratio +

$+0.393688 *$ GDP per capita $+317.248 *$ labour productivity.

If the employment ratio variable rises by $1 \%$, the average wage will increase by $\$ 420.915$, assuming the values of the remaining two explanatory variables remain unchanged. Similarly, if per capita GDP rises by $\$ 1$, the average wage will increase by $\$ 0.393688$, the other two variables not changing. Finally, if the labour productivity variable grows by $\$ 1$, the average wage will rise by $\$ 317.248$ provided that the two remaining values stay the same. As expected, all the three selected explanatory variables affect the average wage in the positive direction.

Figures 7 and 8 display the results of the cluster analysis of the OECD countries applied to all the eight variables researched and the selected four ones, respectively.

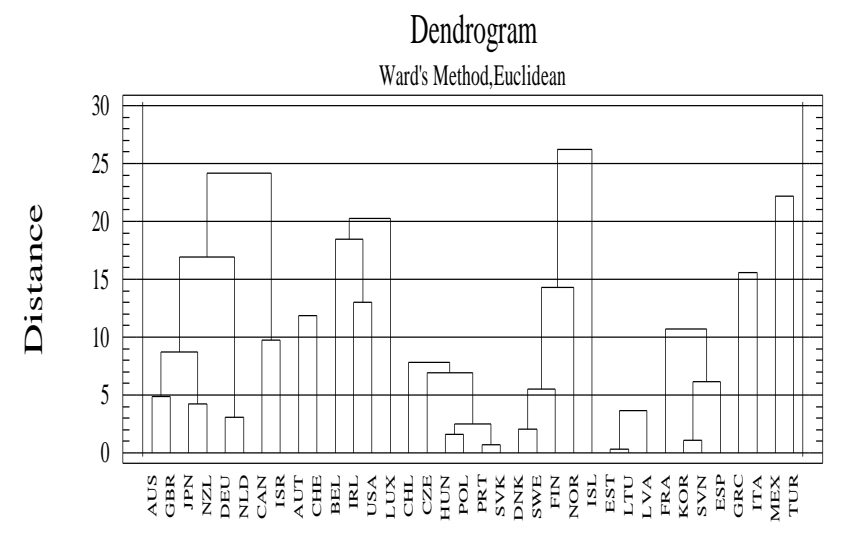

Source: Output from software

Figure 7. Results of Cluster Analysis Applied to All Eight Variables

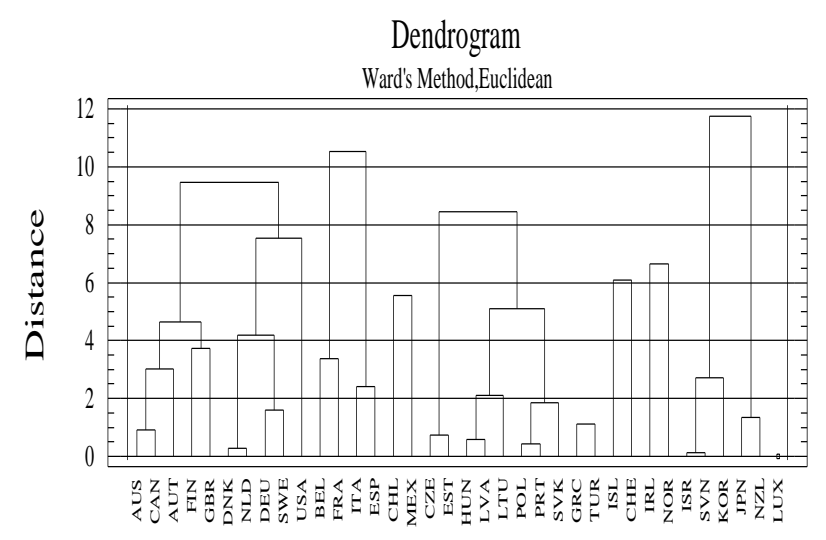

Source: Output from software

Figure 8. Results of Cluster Analysis Applied to Four Selected Variables
In Figure 7 (all variables), the first three clusters are made up of the developed countries, the $1^{\text {st }}$ group containing eight (Australia, Canada, Germany, Israel, Japan, the Netherlands, New Zealand, the U.K.), the $2^{\text {nd }}$ only two (Austria, Switzerland) and the $3^{\text {rd }}$ four (Belgium, Ireland, Luxembourg, the U.S.) countries. The $4^{\text {th }}$ cluster consists of six countries (Chile, the Czech Republic, Hungary, Poland, Portugal, Slovakia), four of which are post-communist ones. The $5^{\text {th }}$ cluster comprises five advanced Nordic countries (Denmark, Finland, Iceland, Norway, Sweden). The Baltic states (Estonia, Latvia, Lithuania) form the $6^{\text {th }}$ group. The $7^{\text {th }}$ cluster has four countries (France, South Korea, Slovenia, Spain), the $8^{\text {th }}$ and $9^{\text {th }}$ groups consisting of two countries each (Greece, Italy and Mexico and Turkey, respectively).

In Figure 8 (four variables), the $1^{\text {st }}$ cluster is made up of ten countries (Australia, Austria, Canada, Denmark, Finland, Germany, the Netherlands, Sweden, the U.K., the U.S.). The $2^{\text {nd }}$ cluster contains four countries (Belgium, France, Italy, Spain). The $3^{\text {rd }}$ group is formed by two Latin American states (Chile, Mexico). The $4^{\text {th }}$ cluster consists of eight countries (the Czech Republic, Estonia, Hungary, Latvia, Poland, Slovakia, Lithuania, Portugal), most of them former socialist ones. The $5^{\text {th }}, 6^{\text {th }}$ and $7^{\text {th }}$ clusters comprise two members each (Greece and Turkey, Iceland and Switzerland, Ireland and Norway, respectively). The $8^{\text {th }}$ cluster contains five (Israel, Japan, South Korea, New Zealand and Slovenia) and the $9^{\text {th }}$ one only one country (Luxembourg).

The knowledge of the composition of groups of countries with similar economic indicator values that regularly occur in common clusters allows for their comparison with classification by the Human Development Index (HDI) - a statistical tool for measuring key dimensions of human development, such as life expectancy, access to education and the standard of living.

The main objective of the OECD is to coordinate policies of the long-term economic development. The OECD unites the most advanced countries which produce more than two-thirds of the world's goods and services, confronting the challenges of economic globalization. That is why it is important to identify the groups of countries with similar economic indicator values, this study's variables being good examples of such data. A comparison of these coherent clusters with, for example, G7 or former socialist countries also appears useful in terms of the world economy integration in connection with foreign investments and international trade.

The blocks of the OECD countries broken down by their geographical location and historical and long-term economic development do not fully coincide with the groups of countries whose cluster analysis results are similar. However, there are many countries which are always in the same group, whether they are clustered by all eight or selected four variables analysed. These groups of countries are listed in Table 2 . The first one comprises four countries, two of them belonging to the block of advanced non-European countries, the other two to the block of continental OECD states. The second group is made up of three countries which are also among the advanced nonEuropean countries. The third group consists of two 
Diana Bilkova. Wage Level as One of the Most Important Indicators of the Quantitative Aspect of the Standard of...

Scandinavian countries. The fourth one contains four states that belong to the Central European block of postcommunist countries plus one southern European country. Finally, the fifth group is made up of the three Baltic states that used to be a part of the Soviet Union.

Table 3 gives predictions of the average wage by 2022 for individual OECD member countries, except for Turkey. The expected average annual wage growth rates for the period 2018-2022 show that the highest ones being predicted for the Baltic states, namely $4.58 \%, 3.66 \%$ and $2.15 \%$ for Latvia, Lithuania and Estonia, respectively.

A relatively fast average wage growth can be also expected in most Central European countries, namely in the Czech Republic (3.44\%), Slovakia (2.75\%), Poland $(2.58 \%)$ and Hungary $(2.51 \%)$. The rapid annual increase in the average wage is also projected for Iceland $(2.38 \%)$. The lowest wage growth values, on the other hand, are forecast for South-European countries - Greece, Italy and Portugal.

Table 2

Groups of Countries that are Always in the Same Cluster (for Both Eight and Four Variables Analysed)

\begin{tabular}{|c|c|c|c|c|}
\hline \multicolumn{5}{|c|}{ Groups of countries } \\
\hline Group 1 & Group 2 & Group 3 & Group 4 & Group 5 \\
\hline $\begin{array}{l}\text { 1. Australia } \\
\text { 2. Canada } \\
\text { 3. Germany } \\
\text { 4. Netherlands }\end{array}$ & $\begin{array}{l}\text { 1. Israel } \\
\text { 2. Japan } \\
\text { 3. New Zealand }\end{array}$ & $\begin{array}{l}\text { 1. Denmark } \\
\text { 2. Finland }\end{array}$ & $\begin{array}{l}\text { 1. Czech Republic } \\
\text { 2. Hungary } \\
\text { 3. Poland } \\
\text { 4. Portugal } \\
\text { 5. Slovak Republic }\end{array}$ & $\begin{array}{l}\text { 1. Estonia } \\
\text { 2. Latvia } \\
\text { 3. Lithuania }\end{array}$ \\
\hline
\end{tabular}

Source: Output from software

Table 3

Average Wage Prediction by 2022 (in USD)

\begin{tabular}{|c|c|c|c|c|c|c|}
\hline \multirow{2}{*}{ Block of countries } & \multirow[b]{2}{*}{ Country } & \multicolumn{5}{|c|}{ Prediction for year } \\
\hline & & 2018 & 2019 & 2020 & 2021 & 2022 \\
\hline \multirow{7}{*}{ Continental } & 1. AUT & 51,219 & 51,681 & 52,142 & 52,604 & 53,066 \\
\hline & 2. BEL & 49,721 & 49,766 & 49,812 & 49,857 & 49,903 \\
\hline & 3. FRA & 44,179 & 44,593 & 45,007 & 45,421 & 45,836 \\
\hline & 4. DEU & 48,613 & 49,368 & 50,123 & 50,878 & 51,633 \\
\hline & 5. LUX & 62,917 & 63,455 & 63,992 & 64,530 & 65,067 \\
\hline & 6. NLD & 53,089 & 53,298 & 53,508 & 53,717 & 53,926 \\
\hline & 7. CHE & 63,651 & 64,065 & 64,479 & 64,892 & 65,306 \\
\hline \multirow{4}{*}{ Scandinavian } & 1. DNK & 51,935 & 52,404 & 52,873 & 53,342 & 53,811 \\
\hline & 2. FIN & 43,247 & 43,531 & 43,814 & 44,097 & 44,381 \\
\hline & 3. NOR & 51,941 & 52,669 & 53,397 & 54,126 & 54,854 \\
\hline & 4. SWE & 43,519 & 44,202 & 44,885 & 45,568 & 46,250 \\
\hline \multirow{2}{*}{ Anglo-Saxon } & 1. IRL & 47,763 & 48,178 & 48,593 & 49,008 & 49,423 \\
\hline & 2. GBR & 43,969 & 44,205 & 44,442 & 44,679 & 44,916 \\
\hline \multirow{4}{*}{ South-European } & 1. GRC & 26,226 & 26,176 & 26,126 & 26,076 & 26,026 \\
\hline & 2. ITA & 36,635 & 36,611 & 36,588 & 36,564 & 36,541 \\
\hline & 3. PRT & 25,369 & 25,296 & 25,223 & 25,150 & 25,077 \\
\hline & 4. ESP & 39,452 & 39,569 & 39,685 & 39,802 & 39,919 \\
\hline \multirow{3}{*}{ Baltic } & 1. EST & 24,887 & 25,439 & 25,990 & 26,541 & 27,093 \\
\hline & 2. LVA & 25,204 & 26,441 & 27,678 & 28,915 & 30,152 \\
\hline & 3. LTU & 25,263 & 26,238 & 27,214 & 28,189 & 29,165 \\
\hline \multirow{5}{*}{ Central-European } & 1. CZE & 26,231 & 27,181 & 28,131 & 29,081 & 30,031 \\
\hline & 2. HUN & 23,180 & 23,785 & 24,389 & 24,994 & 25,598 \\
\hline & 3. POL & 27,225 & 27,956 & 28,687 & 29,418 & 30,149 \\
\hline & 4. SVK & 25,239 & 25,964 & 26,688 & 27,413 & 28,137 \\
\hline & 5. SVN & 35,310 & 35,686 & 36,063 & 36,440 & 36,816 \\
\hline North-Atlantic & 1. ISL & 63,351 & 64,915 & 66,479 & 68,043 & 69,607 \\
\hline \multirow{7}{*}{ Advanced non-European } & 1. AUS & 49,368 & 49,603 & 49,839 & 50,075 & 50,311 \\
\hline & 2. CAN & 48,081 & 48,540 & 48,998 & 49,456 & 49,915 \\
\hline & 3. ISR & 35,322 & 35,577 & 35,831 & 36,086 & 36,341 \\
\hline & 4. JPN & 40,748 & 40,780 & 40,811 & 40,843 & 40,874 \\
\hline & 5. NZL & 40,560 & 41,075 & 41,591 & 42,107 & 42,622 \\
\hline & 6. KOR & 35,791 & 36,391 & 36,990 & 37,590 & 38,190 \\
\hline & 7. USA & 61,871 & 62,420 & 62,970 & 63,519 & 64,069 \\
\hline \multirow{3}{*}{ Developing non-European } & 1. CHL & 18,861 & 19,077 & 19,292 & 19,508 & 19,724 \\
\hline & 2. MEX & 15,411 & 15,421 & 15,430 & 15,439 & 15,448 \\
\hline & 3. TUR & - & - & - & - & - \\
\hline
\end{tabular}

Source: Own research

There are striking differences between some Western and Eastern European wage levels. In Luxembourg, the PPP-adjusted average wage rose up to USD 63,062 in 2017 , the outlook remaining optimistic since the economy is constantly in great shape; GDP per capita (PPP USD 86,788 ) and, consequently, the average wage is the highest in the world. (Luxembourg GDP per capita is influenced by the fact that about one third of the workforce consists of foreigners commuting to the country.) Generally, the wage level tends to grow with rising GDP.

The highest 2017 levels of per capita GDP, average wage and purchasing power are reported by advanced countries such as Switzerland, the United States, Norway, the Netherlands and Iceland. Switzerland is characterized 
by an integrated, efficient economy, $90 \%$ of its GDP being generated by small and medium-sized enterprises. The United States is a major industrial and financial power with strong commercial and $\mathrm{R} \& \mathrm{D}$ sectors and very high consumption of resources (oil and gas in particular). As a non-EU highly developed industrial state with a high degree of sectoral specialization in fishing, oil and gas mining, Norway is a pioneer in clean energy, $99 \%$ of which being produced by hydropower facilities.

One of the wealthiest countries in the world, the Netherlands, boasts of its electrical engineering, chemical, mining and consumer goods industries, generating most energy from natural gas power plants. Iceland is also rich in hydro-energetic and geothermal resources its industries being confined to fisheries and food processing.

Mexico, on the other hand, is the country with both the lowest GDP per capita and average wage (PPP USD 17,123 and 15,314 , respectively), its economy primarily relying on the export of abundant raw materials and agricultural products. Chile, Greece, Portugal, Turkey, the Baltic countries and other former socialist states Hungary, Poland and Slovakia - are among the OECD countries reporting the lowest GDP, wage levels and the purchasing power of the population.

\section{Conclusion}

Average wage developments being indicative of GDPmeasured economic strength, labour market functioning and living standards, the relationship between the level of wages and per capita GDP (i.e. the key factors of the standard of living), however, is not adequately addressed in existing studies. Assuming the wage distribution is influenced by other variable indicators too - the minimum wage, tertiary education attainment, employment ratio, trade unions, labour productivity and inflation have been considered in the present paper.

The basic conclusion to be drawn is that of the seven potential explanatory indicators only three - employment ratio, GDP per capita and labour productivity - affect the average wage in a statistically significant manner, influencing it positively. In the macroeconomic view, it follows logically that the average wage increases along with the growth of the employment ratio, GDP per capita and labour productivity. Using the constructed multiple regression model, it is possible to explain more than $80 \%$ of the variability of the average wage values, which indicates that the model is of high quality. Paradoxically, the employment ratio affects the average wage the most, GDP per capita and labour productivity being the second and third most influential factors, respectively. The theoretical outcome of this research is the determination of economic indicators that can be practically applied by the OECD governments in their national wage policies.

Based on the given economic indicators, the classification of the OECD countries into different clusters proves highly informative about the current era of economic globalization and political convergence following the integration of post-communist countries. The results of the cluster analysis, however, reflect only approximately the division of all 36 current OECD member countries into the original nine blocks according to geographical location, historical background and longterm economic development. For example, Australia, Canada, Germany and the Netherlands are all in one cluster which (except for Canada) corresponds to the part of the continental block. Similarly, Israel, Japan and New Zealand fall into one group in both cases of cluster analysis, overlapping with the advanced non-European country block. Also, two Nordic countries (Denmark and Finland), all the three Baltic successor states of the former Soviet Union and other post-communist countries of Central Europe (except Slovenia) always come together in the same clusters in both parts of the analysis. The theoretical lesson to be learned by the governments of the OECD countries is that their current economic condition is still strongly influenced by the relevant contributing factors, namely their geographical location, history and long-term economic development.

The study also provides five-year wage growth predictions for individual OECD member countries. Based on the analysis of average wage time series, the fastest growth of the average wage by 2022 can be expected in the Baltic countries. A relatively fast increase is also anticipated in Central European post-communist countries (except for Slovenia) and Iceland. By contrast, there is a risk of falling wage levels by 2022 in Southern European countries (except Spain). Theoretically, the aforementioned development may also affect the inflation rate or even interest rates, which might follow the wage level trend.

The difference between the wage as the price of labour and the prices of other production factors lies primarily in the special nature of the workforce, which is shaped by many socio-economic factors determining its position in the production process and behaviour in the labour market.

\section{Acknowledgement}

This paper was subsidized by the funds of institutional support of a long-term conceptual advancement of science and research number IP400040 at the Faculty of Informatics and Statistics, University of Economics, Prague, Czech Republic.

\section{References}

Acemoglu, D. (2003). Cross-Country Inequality Trends. The Economic Journal, 113(485), F121-F149. https://doi.org/10. $1111 / 1468-0297.00100$

Alderson, A. S., \& Nielsen, F. (2002). Globalization and the Great U-Turn: Income Inequality Trends in 16 OECD Countries. American Journal of Sociology, 107(5), 1244-1299. https://doi.org/10.1086/341329 
Diana Bilkova. Wage Level as One of the Most Important Indicators of the Quantitative Aspect of the Standard of...

Arulampalam, W., Devereux, M. P., \& Maffini, G. (2012). The Direct Incidence of Corporate Income Tax on Wages. European Economic Review, 56(6), 1038-1054. https://doi.org/10.1016/j.euroecorev.2012.03.003

Atkinson, A. B. (2003). Income Inequality in OECD Countries: Data and Explanations. CESifo Economic Studies, 49(4), 479-513. https://doi.org/10.1093/cesifo/49.4.479

Atkinson, A. B. (2007). The Distribution of Earnings in OECD Countries. International Labour Review, 146(1/2), 41-60. https://doi.org/10.1111/j.1564-913X.2007.tb00043.x

Baccaro, L., \& Rei, D. (2007). International Determinants of Unemployment in OECD Countries: Does the Deregulatory View Hold Water? International Organisation, 61(3), 527-569. https://doi.org/10.1017/S0020818307070221

Bardasi, E., \& Gornick, J. C. (2008). Working for Less? Women's Part-Time Wage Penalties across Countries. Feminist Economics, 14(1), 37-72. https://doi.org/10.1080/13545700701716649

Bartelsman, E. J., \& Beetsma, R. M. W. J. (2003). Why Pay More? Corporate Tax Avoidance through Transfer Pricing in OECD Countries. Journal of Public Economics, 87(9/10), 2225-2252. https://doi.org/10.1016/S00472727(02)00018-X

Bilkova, D. (2019). Assessment of Living Standard Indicators in the OECD Member Countries. ACC Journal, 25(2), 2145. https://doi.org/10.15240/tul/004/2019-2-002

Blanchflower, D. G. (2001). Unemployment, Well-Being, and Wage Curves in Eastern and Central Europe. Journal of the Japanese and International Economies, 15(4), 364-402. https://doi.org/10.1006/jjie.2001.0485

Bornhorst, F., \& Commander, S. (2006). Regional Unemployment and Its Persistence in Transition Countries. Economics of Transition, 14(2), 269-288. https://doi.org/10.1111/j.1468-0351.2006.00254.x

Brockwell, P. J., \& Davis, R. A. (2002). Introduction to Time Series and Forecasting. New York: Springer. https://doi.org/10.1007/b97391

Checchi, D., \& Garcia-Penalosa, C. (2010). Labour Market Institutions and the Personal Distribution of Income in the OECD. Economica, 77(307), 413-450. https://doi.org/10.1111/j.1468-0335.2009.00776.x

Clark, A. E. (2005a). Your Money or Your Life: Changing Job Quality in OECD Countries. British Journal of Industrial Relations: An International Journal of Employment Relations, 43(3), 377-400. https://doi.org/10.1111/j.14678543.2005.00361.x

Clark, A. (2005b). What Makes a Good Job? Evidence from OECD Countries. In: S. Bazen, C. Lucifora, \& W. Salverda (Eds.), Job Quality and Employer Behaviour (pp. 11-30). London: Palgrave Macmillan. https://doi.org/10.1057/ 9780230378643_2

Darlington, R. B., \& Hayes, A. F. (2017). Regression Analysis and Linear Models: Concepts, Applications, and Implementation. New York: The Guilford Press.

Docquier, F., Ozden, Ç., \& Peri, G. (2013). The Labour Market Effects of Immigration and Emigration in OECD Countries. The Economic Journal, 124(579), 1106-1145. https://doi.org/10.1111/ecoj.12077

Dustmann, C., \& Glitz, A. (2010). Employment, Wages, and the Economic Cycle: Differences between Immigrants and Natives. European Economic Review, 54(1), 1-17. https://doi.org/10.1016/j.euroecorev.2009.04.004

Falk, M., \& Wolfmayr, Y. (2008). Services and Materials Outsourcing to Low-Wage Countries and Employment: Empirical Evidence from EU Countries. Structural Change and Economic Dynamics, 19(1), 38-52. https://doi.org/10.1016/j.strueco.2007.12.001

Fortin, N. M. (2005). Gender Role Attitudes and the Labour-Market Outcomes of Women across OECD Countries. Oxford Review of Economic Policy, 21(3), 416-438. https://doi.org/10.1093/oxrep/gri024

Freeman, R., \& Schettkat, R. (2001). Skill Compression, Wage Differentials, and Employment: Germany vs the US. Oxford Economic Papers, 53(3), 582-603. https://doi.org/10.1093/oep/53.3.582

Gannon, B., Plasman, R., Ryex, F., \& Tojerow, I. (2007). Inter-Industry Wage Differentials and the Gender Wage Gap: Evidence from European Countries. Economic and Social Review, 38(1), 135-155.

Gaston, N., \& Nelson, D. (1997). Globalisation and Wages in OECD Economies: Linking Theory with Evidence. School of Business Bond University. Preliminary Draft.

Available from: http://www.tulane.edu/ dnelson/PAPERS/GastonNelson.pdf

Guvenen, F., Kuruscu, B., \& Ozkan, S. (2013). Taxation of Human Capital and Wage Inequality: A Cross-Country Analysis. The Review of Economic Studies, 81(2), 818-850. https://doi.org/10.1093/restud/rdt042

Holden, S., \& Wulfsberg, F. (2008). Downward Nominal Wage Rigidity in the OECD. The B. E. Journal of Macroeconomics, 8(1), 1935-1690. https://doi.org/10.2202/1935-1690.1651 
Johnston, A., \& Hancke, B. (2009). Wage Inflation and Labour Unions in EMU. Journal of European Public Policy, 16(4), 601-622. https://doi.org/10.1080/13501760902872742

Koeniger, W., Leonardi, M., \& Nunziata, L. (2007). Labor Market Institucions and Wage Inequality. ILR Review, 60(3), 340-356. https://doi.org/10.1177/001979390706000302

Kus, B. (2012). Financialisation and Income Inequality in OECD Nations: 1995-2007. The Economic and Social Review, 43(4), 477-495.

Leuven, E., \& Oosterbeek, H. (2004). Explaining International Differences in Male Skill Wage Differentials by Differences in Demand and Supply of Skill. The Economic Journal, 114(495), 466-486. https://doi.org/10. 1111/j.1468-0297.2004.00217.x

Lucifora, C., McKnight, A., \& Salverda, W. (2005). Low-Wage Employment in Europe: A Review of the Evidence. Socio-Economic Review, 3(2), 259-292. https://doi.org/10.1093/SER/mwi011

Macinko, J. A., Shi, L., \& Starfield, B. (2004). Wage Inequality, the Health System, and Infant Mortality in Wealthy Industrialized Countries, 1970-1996. Social Science \& Medicine, 58(2), 279-292. https://doi.org/10.1016/S02779536(03)00200-4

Millea, M. (2002). Disentangling the Wage-Productivity Relationship: Evidence from Selected OECD Member Countries. International Advances in Economic Research, 8(4), 314-323. https://doi.org/10.1007/BF02295506

Naastepad, C. W. M., \& Storm, S. (2006). OECD Demand Regimes (1960-2000). Journal of Post Keynesian Economics, 29(2), 211-246. https://doi.org/10.2753/PKE0160-3477290203

Nunziata, L. (2005). Institutions and Wage Determination: A Multi-Country Approach. Oxford Bulletin of Economics and Statistics, 67(4), 435-466. https://doi.org/10.1111/j.1468-0084.2005.00127.x

Plasman, R., Rusinek, M., \& Rycx, F. (2007). Wages and the Bargaining Regime under Multi-Level Bargaining: Belgium, Denmark and Spain. European Journal of Industrial Relations, 13(2), 161-180. https://doi.org/10. 1177/0959680107078251

Pollin, R., Burns, J., \& Heintz, J. (2004). Global Apparel Production and Sweatshop Labour: Can Raising Retail Prices Finance Living Wages? Cambridge Journal of Economics, 28(2), 153-171. https://doi.org/10.1093/cje/28.2.153

Rencher, A. C., \& Christensen, W. F. (2012). Methods of Multivariate Analysis. New Jersey: John Wiley \& Sons. https://doi.org/10.1002/9781118391686

Rueda, D., \& Pontusson, J. (2000). Wage Inequality and Varieties of Capitalism. World Politics, 52(3), 350-383. https://doi.org/10.1017/S0043887100016579

Sener, F. (2001). Schumpeterian Unemployment, Trade and Wages. Journal of International Economics, 54(1), $119-533$. https://doi.org/10.1016/S0022-1996(00)00086-6

Sjoberg, O. (2008). Corporate Governance and Earnings Inequality in the OECD Countries 1979-2000. European Sociological Review, 25(5), 519-533. https://doi.org/10.1093/esr/jen069

Soskice, D., \& Iversen, T. (2000). The Nonneutrality of Monetary Policy with Large Price or Wage. The Quarterly Journal of Economics, 115(1), 265-284. https://doi.org/10.1162/003355300554737

Van Reenen, J. (2011). Wage Inequality, Technology and Trade: 21st Century Evidence. Labour Economics, 18(6), 730741. https://doi.org/10.1016/j.labeco.2011.05.006

Van Rijckeghem, C., \& Weder, B. (2001). Bureaucratic Corruption and the Rate of Temptation: Do Wages in the Civil Service Affect Corruption, and by How Much? Journal of Development Economics, 65(2), $307-331$. https://doi.org/10.1016/S0304-3878(01)00139-0

Wolff, G. B., \& Reinthaler, V. (2008). The Effectiveness of Subsidies Revisited: Accounting for Wage and Employment Effects in Business R \& D. Research Policy, 37(8), 1403-1412. https://doi.org/10.1016/j.respol.2008.04.023

The article has been reviewed.

Received in May 2019; accepted in June 2020. 